\title{
Za návrat k ranému Durkheimovi. Kulturněsociologické inspirace v Pravidlech sociologické metody a Společenské dělbě práce'
}

\author{
For a Return to the Early Durkheim. Cultural-sociological \\ Inspirations in The Rules of Sociological Method \\ and The Division of Labour in Society \\ Vít Horák
}

\begin{abstract}
The idea of cultural sociology was started by a new perspective on the French sociological classic Émile Durkheim that was presented in a book titled Durkheimian Sociology: Cultural Studies, edited by Jeffrey Alexander (1988). It rejected the view of Durkheim as a positivist materialist and forerunner of structural functionalism and systems theory, and discovered in Durkheim a theoretician of religion, culture, and a subjectivistic Durkheim. With this interpretation Alexander connected the distinctive periodisation of Durkheim's work, which is based on the radical discrepancy between the early and the late Durkheim. The inspiration for cultural sociology came almost exclusively from the late period around the book Elementary Forms of the Religious Life. This article, in contrast, explores Durkheim's early works The Rules of Sociological Method and The Division of Labour in Society - and seeks new inspirations for cultural sociology. Regarding the former book, this approach rehabilitates Durkheim's positivism, which need not be understood as contradictory to cultural sociology. It could contribute to the discussion about the autonomy of culture. Regarding the latter, I want to distinguish between the economic and cultural spheres and discuss how cultural sociology can understand the concepts of division of labour and solidarity. I put special emphasis on the two general types of interpersonal mutuality (mutual resemblance and complementary disimilarity), that for Durkheim were the basis for the concepts of mechanical and organic solidarity. I assume that these two types can be useful for the cultural sociological notion of identity.
\end{abstract}

KEYWORDS Émile Durkheim, Jeffrey Alexander, cultural sociology, The Rules of Sociological Method, The Division of Labour in Society, positivism

\section{Úvod}

Kulturní sociologie Jeffreyho Alexandera nachází silný základ v díle Émila Durkheima. Její inspirační zdroje jsou jistě bohatší, ale minimálně v rámci klasické sociologie je Durkheim

Sociálni studia. Katedra sociologie FSS MU, 4/2012. S. 13-26. ISSN 1214-813X.

1 Tento text vznikl v rámci řešení grantového projektu Grantové agentury Univerzity Karlovy č. $696012 / 2012$. 
jejím nejdůležitějším předchůdcem a inspiračním zdrojem. Ostatně, dá se říct, že celá myšlenka kulturní sociologie, která staví na převrácení vztahu kultury a sociální struktury, ${ }^{2}$ odstartovala reinterpretací klasikova díla právě pod vedením Jeffreyho Alexandera (1988). Ač ani starší čtení Durkheima nebylo jednoznačné, nejčastěji byl chápán jako otec „přírodovědecké“ sociologie a teoretik konsenzualismu, kladoucí důraz na normativní regulaci jednotlivce. To Alexanderovu plánu na emancipaci kulturní sféry a interpretativního př́stupu $\mathrm{k}$ sociologii nemohlo vyhovovat. Přenesl proto pozornost na pozdní fázi klasikova díla $\mathrm{v}$ čele s jeho poslední velkou monografií Elementární formy náboženského života (1912). Toto období od předchozího díla oddělil s poukazem na to, že v Durkheimově díle je patrný obrat. ${ }^{3}$ Tím ovšem také posvětil dosavadní interpretaci raných děl. Domnívám se, že tento závěr není nutný a že nic nebrání interpretovat kulturněsociologicky i raného Durkheima.

Oprávněnost tohoto směřování naznačuje několik skutečností:

1) Alexander tezi o obratu přejímá od Parsonse, ${ }^{4}$ který v pozdním Durkheimovi hledal podporu pro svoji voluntaristickou teorii jednání. Ta ovšem míři přesně opačným směrem než kulturní sociologie. Jejím motivem bylo Durkheima definovat jako představitele radikálního sociologismu, jehož nejzazším horizontem byl hodnotový konsenzus (Parsons 1968: 466 a kapitoly 9 až 11). Je minimálně podivné, že Alexanderova interpretace Durkheima je tak podobná Parsonsově, a přitom u obou autorů slouží k podpoře diametrálně odlišných tezí.

2) Parsonsova či Alexanderova teze o obratu se setkala se spíše odmítavými reakcemi. ${ }^{5}$ Je sice velmi důležité, že Durkheim rozpoznal ústřední roli náboženství, ale došlo k tomu už v roce $1895^{6}$ (rok vydání Pravidel sociologické metody), tedy relativně brzy v jeho teoretické dráze. Přechod mezi materialistickou a spiritualistickou (idealistickou) fází díla, které obhajuje Alexander, u pozdního Durkheima najdeme těžko (Thompson 1982: 40).

3) I v samotné publikaci, která odstartovala nové čtení Durkheima, najdeme text, který se explicitně věnuje ranému dílu (Wallace a Hartley 1988). Výzkumný zájem kulturních sociologů tedy není dominantně obrácen $\mathrm{k}$ Elementárním formám náboženského života.

2 Srv.: „Kritická linka v jádru současných debat leží mezi ,kulturní sociologií‘ a ,sociologií kultury“. Věřit v možnost kulturní sociologie znamená přihlásit se k myšlence, že každé jednání, bez ohledu na to jestli je instrumentální, reflexivní nebo vnucené vnějším prostředím (Alexander 1988), je do určité míry zakořeněno $\mathrm{v}$ horizontu afektu a významu. Vůči tomuto vnitřnímu prostředí aktér nikdy nemůže zaujmout plně instrumentální či reflexivní pozici“ (Alexander 2003: 12 a v širším kontextu s. 11-26).

3 V raném Durkheimovi lze podle Alexandera vypozorovat materialismus, mechanistický funkcionalismus, objektivismus a instrumentální chápání sociální struktury, v pozdním potom idealismus, subjektivismus, důraz na afektivitu a solidaritu, symbolickou rovinu a kolektivní reprezentace (Alexander 2008).

$4 \quad$ Nutno podotknout, že Parsons nebyl jediný, kdo hovořil o dvou rozdílných Durkheimech. Podobný názor sdílel např́ílad Raymond Aron, viz Aron (1967).

5 Giddens (1971: 105) kritizuje představy obratu v Durkheimově díle, které nachází už u Parsonse. Nisbet (1975: 50-51) se rovněž staví proti. A nesouhlasí ani Collins (2002: 132-133), který se sám projektu kulturní sociologie účastní.

6 Durkheim v této souvislosti mluví dokonce o zjevení (Lukes 1973: 237). 
4) Tématem poslední Durkheimovy velké monografie není přímo kultura, ale náboženství, a v kulturní sociologii tyto pojmy až př́liš lehko splývají. Kultura se pak zdá být pouze soustavou rituálů a kolektivních reprezentací. Je nasnadě, že má-li být kultura chápána obecně, musí mít i širší pojmové zázemí.

Abychom získali př́stup $\mathrm{k}$ ranému Durkheimovi, je dle mého názoru nutné zbavit se Parsonsovy interpretace, na které je Alexander příliš závislý. Znamená to sociální sféru vyvázat z vlivu normativní orientace a idealismu a navrátit ji tomu, co Parsons označuje jako prostředí (environment). ${ }^{7,8}$ Budu se proto snažit rehabilitovat Durkheimův positivismus, který Parsons odmítl ve prospěch svého voluntarismu. Positivismus však, jak jsem přesvědčen, je možno chápat zcela $\mathrm{v}$ duchu kulturní sociologie. Tomu věnuji první část textu. Druhá část se bude týkat Durkheimových představ o sociologii, jejímu předmětu a metodě, které autor předložil v Pravidlech sociologické metody (dále jen Pravidla). V poslední části textu pak naznačím kulturněsociologickou interpretaci díla Společenská dělba práce, která staví na dvou typech mezilidské vzájemnosti a specifickém chápání pojmů solidarity a dělby práce. Civilizační vývoj, který Durkheim popisuje na základě přesunu od mechanické k organické solidaritě, se pokusím interpretovat jako proměnu lidské identity, spíš než změnu v charakteru ekonomické organizace.

\section{Positivismus}

V základu argumentace tohoto textu je specifická interpretace positivismu. Nutno poznamenat, že Durkheim se k positivismu sám př́mo nehlásil. Vůbec nesl nelibě, když byl přiřazován k dobovým směrům (materialismus, idealismus, antipsychologismus). Prohlašoval se pouze za racionalistu, což je nálepka nepř́liš profilující. Je zřejmě nutné přijmout fakt, že Durkheim byl s teoretickými směry v jejich soudobé podobě nespokojen a nedokázal se k nim přihlásit. Hledal vlastní pozici. Neměl to být zcela nový filosofický směr, ale spíše svébytný výběr ze stávajících filosofických a sociálněvědních teorií. Přesto není sporu o tom, že positivismus Durkheima významně ovlivnil a že se pohyboval v jeho tradici.

Positivismus byl pokusem začlenit sociální realitu mezi oblasti, na které je možno aplikovat novověkou prŕrodovědeckou metodu. Tento pokus měl dva aspekty: ontologický - společnost se stala oblastí, která připouštěla vědecké zkoumání - a metodologický - při zkoumání tohoto předmětu měly být aplikovány stejné postupy jako v přírodních vědách. Revoluční osten prvního aspektu se poměrně rychle otupil. Naopak dlouhý život má kontroverze ohledně vhodných metod pro sociální vědu. Můžeme ke zkoumání společnosti použít stejné postupy jaké používají přírodní vědy? Nebo jinak: závisí úspěch vědy právě na aplikaci těchto postupů, nebo jádro vědeckého přístupu tkví v něčem jiném a tyto metody jsou

Parsonsovy deklarace k nalezení v Parsons (1968: 464).

8 Alexander sice rovněž odmítá zásadní vliv vnějšího (objektivního) prostředí, ale současně přisuzuje velký význam prostředí vnitřnímu, jež lze chápat jako soustavu zděděných kulturních vzorců. Domnívám se, že toto rozlišení není udržitelné a že v rámci kulturní sociologie lze pojem prostředí přijmout právě v okamžiku, kdy jej nerozdělujeme na vnější a vnitřní či subjektivní a objektivní. 
pouhými nástroji, které pomáhají k cíli? Toto dilema je živé i dnes po mnoha letech drtivé postmoderní kritiky. Asi proto, že př́rodovědecká metoda je svázána i s kýženým výstupem vědy - s matematicky formulovanými zákony. Když jej odmítneme, ztrácí se i ponětí o tom, jaké vědění by vlastně věda měla produkovat. Sociologové sice vždycky byli silnými kritiky universalismu prŕrodovědecké metody, ale nikdy neuvažovali o tom, že by se vzdali statusu vědce a kritizovali vědu ,zvenčí“. Napětí mezi metodologickým positivismem a antipositivismem ${ }^{9}$ je proto stále živé, zatímco spor o sociologii jako takovou, na kterém byl vybudován positivismus 19. století, je už téměř zapomenut. Nešlo v něm tolik o metodu, jako o samotnou existenci sociální vědy. V tomto smyslu se dá říct, že všichni sociologové jsou (ontologičtí) positivisté, byt' na metodologii sociálních věd mají velice odlišné názory.

Pestré metodologické postupy, které neodpovídají úzkoprofilovému metodologismu pozdějších neopositivistů, ovšem nalezneme i v rámci původního positivismu. Speciálně Durkheim byl velmi kritický k dosavadním teoriím, včetně těch positivistických (Comte, Mill). Vždy v nich viděl až príliš snadný redukcionismus. Zaujímal tedy stejný postoj jako pozdější kritikové výzkumných metod v sociologii.

Durkheimova vyjádření k metodě sociologie zůstala spíše v kritické rovině. Ač se jeho hlavní metodologický spis nazývá Pravidla sociologické metody, jeho obsahem není to, co by dnešní sociolog očekával od metodologické publikace positivistického ražení. Kniha nepopisuje, jakým způsobem by měl sociolog při výzkumu postupovat. Věnuje se spíš tomu, co je vlastně předmětem sociologického zájmu a jaký postoj k němu máme zaujmout. Je to kniha epistemologická, ale také ontologická. Její významnou, možná nejdůležitější, část tvoří popis toho, co to vlastně sociální skutečnost je. Durkheim zde obhajuje tezi, že společnost je především skutečnost svébytná, vůči jedincům vnější. Stejně jako další positivisté považuje za skutečné jen to, co je jako vnější př́stupné smyslům. Německý filosof a fyzik Ernst Mach, klasik positivismu, odmítal naprríklad atomy jako pouze pomocné fikce, protože samy nejsou vnímatelné. ${ }^{10}$ Podobně Durkheim v Pravidlech odmítal koncepci užitku či společenského pokroku jako pouhých představ, které do společnosti projikujeme.

$\mathrm{V}$ rámci positivismu můžeme vysledovat dvě různé cesty, které vedou $\mathrm{k}$ tomu, abychom zkoumání založili na čistě vnějších jevech, nikoli na apriorně stanovených vědeckých konstrukcích. První se spoléhá na př́rodovědeckou metodu a měrné veličiny, které mají zaručit, že vnější skutečnost zachytíme objektivně. Druhá se snaží obhájit, že tu vủbec je cosi jako svébytná společnost, jež není pouhou výslednicí individuálních vưlí, a také kritizovat sociologické pojmy, které se jako hotové představy do sociální sféry projikují. Obě cesty sice lze chápat jako komplementární, ale nijak nutně spojeny nejsou, ba mohou být i protikladné. Durkheim byl jistě obhájce, nikoli kritik vědy, ale jeho argumentace v Pravidlech odpovídá

9 Přesnější označení by bylo neopositivismus a antineopositivismus, protože spor o metodu se naplno rozhořel až na začátku 20. století v neopositivismu Vídeňského kroužku. V literatuře se to často nerozlišuje a označení antineopositivismus či postneopositivismus se, pokud vím, nepoužívá vůbec.

10 Viz jeho první zásada positivismu: Zdrojem všeho lidského poznání je to, co je [smyslům] dáno (das Gegebene). 
druhé poloze. Když si odmyslíme obvyklé spojování positivismu s přírodovědeckou metodou, nic nám nebrání přiřadit Durkheimovy myšlenky k pozicím kulturní sociologie.

Alexander se stejně tak od začátku své profesní dráhy snažil o postup co nejdále od účelově racionálního jednání k hlubším kulturním složkám. Ohnisko zájmu přesunul ke kódům, narativům a symbolům, tedy přesně $\mathrm{k}$ tomu, co je individuální vůli nejvzdálenější. Zatímco teorie, které staví na racionální volbě, předpokládají, že vše je v rukách subjektu, kulturní sociologie, stejně tak jako Durkheim, hledá determinanty, které tu jsou ještě před tím, než se někdo rozhoduje.

Alexander se ovšem snaží i o protiklad ke konsenzualistickým teoriím, jejichž nejzazším horizontem je hodnotová či normativní shoda. I to je sféra voluntaristická, jak víme od Parsonse. Konsenzus sice zpětně vytváří vnější limity, ale sám je dohodou mezi subjekty, u níž se kulturní pozadí neuvažuje. To, co je závislé na individuální vůli, nemůže však být podle Durkheimových kritérií považováno za doménu společnosti chápané jako skutečnost sui generis. Chtěl-li Parsons prosadit voluntaristickou teorii jednání, musel tuto fázi Durkheimova díla odmítnout. Alexander k tomu ale nemá důvod. Sám tvrdí, že jeho program kulturní sociologie odmítá sociální strukturu „Zvěcnělých hodnot, norem, ideologie nebo fetišismu“ (Alexander 2003: 13) a snaží se ji přesáhnout směrem k hlubším kulturním významům.

Kódy, narativy a symboly jsou k lidem v jiném vztahu než hodnoty a normy. Člověk se pohybuje už vždy v jejich rámci, nikdy $\mathrm{k}$ nim nemůže zaujmout odstup a v jejich celistvosti je uchopit a přetvořit. Ani hodnoty a normy si nevytváŕíme vědomě a přejímáme je z tradice; ale současně obsahují i určitý apel na to, abychom se k nim s uvědoměním hlásili a prosazovali je (hodnoty), či se př́mo očekává, že s nimi budeme zacházet, potvrzovat je či rušit (normy). I hodnoty a normy samožrejmě mohou být tématem kulturní sociologie, ale přesto musí mít pro ni větší význam trojice kódů, narativů a symbolů, protože ta je tím nejzazším kulturním podkladem, v jehož rámci (vědomé a uvědomělé) individuum povstává.

Stejným směrem musí mířit i Durkheimův positivismus, chce-li zkoumat pouze to dané, a nikoli to, co si člověk sám dává. Kultura tak, jak ji chápe kulturní sociologie, by měla být jeho ideální sférou zájmu. Kultura tu není segmentem lidské aktivity (jako např́iklad umění, náboženské praktiky, folklór), ale spíš vrstvou, která zůstává v základu všech lidských aktivit. Alexander toto analytické pojetí zdědil od Parsonse, který hierarchicky rozložil ekonomiku, politiku, sociální sféru a právě kulturu. ${ }^{11}$ Linka však vede až k Durkheimovi, který společenský jev odlišil právě tím, že spočívá za horizontem dosahu lidské aktivity a vůle. ${ }^{12}$ Bylo to rozlišení analytické, protože společenskou realitu člověk, obzvláště moderní, vnímá většinou individualizovaně jako přání, tužby, preference, cíle, které někdo vědomě sleduje. ${ }^{13}$

11 Limitem Parsonsova pojetí bylo ale právě to, že kulturu chápal pouze jako rámec společných hodnot. Jeho idealistické pojetí potom vyžadovalo doplnění o materialistický rozměr, a Parsons proto kauzální hierarchii na základě teorie sociálních systémů koncipoval i opačně - od ekonomiky směrem ke kultuře. Oba dva směry šlo však jen těžko propojit.

12 Srv.: „Vskutku hlavně poznáme věc podle toho, že nemůže býti měněna pouhým rozhodnutím vůle" (Durkheim 1926: 61).

13 Srv.: „Působí to všechno dosti lehko dojmem, jakoby to netkvělo na ničem a vznášelo se v prázdnu, dojmem hmoty napolo neskutečné“ (Durkheim 1926: 51). 
Durkheim se snažil ukázat, že pod tímto povrchem je cosi základnějšího, z čeho jednání jedinců vychází.

Když tedy opustíme představu positivismu jako metodologického (scientistického) vymezení a chápeme jej jako obhajobu svébytnosti sociální/kulturní sféry a její neredukovatelnosti na lidské rozhodování, můžeme mu rozumět jako předstupni kulturní sociologie. V souladu s předchozí tezí o ontologické, spíš než metodologické (př́padně epistemologické), orientaci positivismu bych nyní chtěl ontologický rozměr blíže identifikovat v Durkheimových Pravidlech.

\section{Podrobněji k Durkheimovým Pravidlům sociologické metody}

Durkheim sociální skutečnost popisuje především v prvních dvou kapitolách, které lze považovat za ty významnější, snad dokonce za samotné jádro práce. První kapitola se nazývá „Co je to společenský jev ${ }^{14}$ ?“ a říká, že společenské jevy jsou ,[...] druhy jednání, myšlení a cítění, které mají tu pozoruhodnou vlastnost, že existují mimo individuální vědomí“. A zároveň ,[...] jsou nadány silou rozkazovací a utlačivou, kterou se mu [jedinci] vnucují, at' již chce či ne“ (Durkheim 1926: 36). ${ }^{15}$

Definice společenského jevu tedy spojuje dvě jeho podstatné vlastnosti: společenský jev je vůči jedinci vnější, ale současně je zamířen jeho směrem. Bez jedinců by byl společenský jev nemyslitelný, je možný jen tak, že je tu pro ně a skrze ně. Durkheim ovšem tento vztah představuje jednostranně jako utlačivou sílu. Zná jen tlak a podlehnutí a chybí mu představa čehosi, co by se dalo nazvat jako chápající osvojení. ${ }^{16}$ Je si vědom, že jedinci společenské mravy internalizují a identifikují se s nimi, ale je to pro něj jen výsledek předchozího výchovného útlaku. Ideálem, který zmiňuje, by pak bylo nechat vyrůstat děti ve spontánní interakci s okolím bez intervence dospělých. Taková teze je celkem zarážející u sociologa, který společnost chápal positivně jako obranu proti dezintegraci a anomii, ve které se ocitá moderní společnost. Stavět společnost za oblast individuální vůle je v souladu s programem kulturní sociologie, ale tento jednostranný dưraz na nátlak orientuje sociologii prŕiliš směrem k právním předpisům; a v širším ohledu na morálku.

14 „Jev“ je překlad původního francouzského „fait“, což je doslova „fakt“. Český výraz „fakt“ ale není přesným překladem, protože v češtině má v porovnání s francouzštinou daleko užší význam. Širší význam si podržel i v angličtině a překládá se tedy jako „fact“, naproti tomu v němčině má význam také úzký a je překládán jako „Tatbestand“ (,stav věci“, „skutečnost“). Z hlediska záměru textu je to rozdíl podstatný, protože fakt by mohl naznačovat, že nám jde pouze o to, co vědecky zaznamenáváme (to, co se ukáže na měřicím př́stroji), a ne o vlastní charakter věci, kterou zkoumáme.

15 Pro úplnost přidejme i kompaktní definici z konce první kapitoly: „Společenským jevem je každý druh jednání, ustálený nebo ne, schopný vnějš́iho tlaku na jedince; anebo takový, který v rozsahu dané společnosti je všeobecný, ale má přitom svůj vlastní život nezávislý na svých individuálních projevech“ (Durkheim 1926: 46).

16 Zde se nabízí propojení s filosofickou hermeneutikou, která propracovala možnosti rozumění jakožto lidského existenciálu. Pojmu-li tento vztah jako rozumějící, chápu člověka jako toho, kdo kulturní vzorce aktivně přejímá a ne jen pasivně přijímá. 
Druhá kapitola začíná slavnou tezí:

První a nejzákladnější pravidlo je, pokládati společenské jevy za věci. (Durkheim 1926: 47)

Význam tohoto hesla je závislý na tom, na co v něm klademe důraz. Čtení epistemologické by kladlo důraz na slovo ,pokládati““ a rozumělo by mu jako instrukci, jaký postoj máme vzhledem k objektu zkoumání zaujmout. V takovém př́padě by nezáleželo na tom, co je zkoumaná skutečnost, ale pouze, jak k ní přistupujeme. Čtení ontologické by naopak akcentovalo přirovnání společenského jevu k věci. Společenské jevy nejsou pojmy, myšlenky ani představy, jsou to věci s vlastní existencí nezávislou na jedinci.

Kdybychom chápali zmíněné heslo jako instrukci, jaký by byl její význam? Durkheim v následujícím textu postupuje hlavně kriticky. Píše, že je nutné vyhnout se užívání předvědeckých a apriorních pojmů. Když ale přichází řeč na otázku, jak by měl sociolog postupovat správně, Durkheim nedává metodologické rady, ale stále se znovu vrací k otázce po charakteru společenské skutečnosti:

Až dosud pojednávala sociologie o pojmech nikoli o věcech. (Durkheim 1926: 48)

Tedy nikoli jak, ale o čem.

Nemůžeme tedy uvádět $\mathrm{v}$ pochybnost jejich existenci. [...] Nemůžeme přece pokládat za neskutečné, co se nám staví na odpor. Všechno tedy shodně nám tu ukazuje pravé společenské skutečno. (tamtéž: 51)

A přece společenské jevy jsou věci [...]. (tamtéž: 59)

V následující pasáži dobře vidíme, že epistemologický rozměr je tu velmi úzce vázán na ontologické vymezení:

Vskutku hlavně poznáme věc podle toho, že nemůže být měněna pouhým rozhodnutím lidské vůle. To neznamená, že by se každé změně vzpírala. Ale, abychom na ní přivodili změnu, $\mathrm{k}$ tomu nestačí pouhá vůle, je také třeba úsilí více méně namáhavého odporu, který klade a který ostatně nemůže býti vždycky přemožen. Viděli jsme, že společenské jevy mají tuto vlastnost. Aniž by byly výtvorem naší vůle, určují ji zvenčí; jsou jakoby kadluby, v nichž jsme nuceni své činy formovati. Často dokonce ta nutnost je tak veliká, že jí nemůžeme uniknouti. Ale i když se nám podaří nad ní zvítěziti, odpor, s nímž se setkáváme, upozorňuje nás dostatečně, že se utkáváme s něčím, co nezávisí na nás. Budeme-li tedy pokládati společenské jevy za věci, přizpůsobíme se pouze jejich povaze. (tamté:̌ 61, kurziva VH)

Čteme charakteristiku společenské skutečnosti sui generis. Máme-li chápat instrukci v závěru jako epistemologickou, pak je vidět, že je jen důsledkem vyplývajícím z předchozí ontologické charakteristiky.

Durkheim dále zdůrazňuje, že sociolog musí přijmout fakt, že se ocitá na počátku zkoumání, a vyvarovat se pojmů, které by jeho výzkumu už předem daly rozhodující směr. 
Myslím, že za tímto požadavkem si nemusíme představovat pouze metodu indukce a sběr dat pomocí dotazníkủ. Těmto představám vyhovuje i třeba zhuštěný popis Clifforda Geertze (Geertz 2000), který je považován za vzor a inspirační zdroj kulturní sociologie. Zhuštěný popis spočívá právě ve shromažd’ování poznatků, téměř bez třídících kritérií, a pouze v pozvolné interpretaci a oddělování podstatného od nepodstatného. ${ }^{17}$ Durkheim nedůvěřuje předvědeckým pojmům, ale současně si uvědomuje, že na nich je výzkumník zpočátku závislý. Varuje před nekritickým přejímáním předvědeckých pojmů, ale i před představou, že by sociolog měl mít jasno už na začátku. Sociolog se nachází ,„[...] na počátku vědy, nemůže být [...] cílem [jeho definice] vyjádřit podstatu skutečnosti; má nás jen uschopniti dospěti k ní později“ (Durkheim 1926: 74). Comta a Milla kritizoval právě za to, že o pokroku, respektive hospodářské orientaci lidského jednání, měli jasno už předem. Symbolický význam, ke kterému se snaží dospět Geertz, se naopak ukáže až později. Takto jednoznačnou interpretaci lze samozřjejmě napadnout, žádná teorie není zcela bez předpokladů, ale durkheimovská metodologie přesto vyniká zvláštní obavou ze zanášení nereflektovaných předpokladů, které předurčují pozdější závěry.

Návrat k Durkheimovým myšlenkám o povaze společenské reality sui generis by mohl prrispět k debatě o autonomii kultury, jež je principiálním tématem kulturní sociologie (Skovajsa 2012). Alexander navazuje na Durkheima, když tvrdí, že vůči kultuře aktér nemůže zaujmout postoj plně instrumentální nebo reflexivní, ale navazuje až na Parsonse, když kulturu chápe jako idealistickou strukturu (obě teze in Alexander 2003: 12). Návrat k Durkheimovi by mohl pomoci opustit zavádějící dělení na idealismus a materialismus. Durkheimův positivismus se brání právě tomu, aby společenský jev byl chápán jako pouhá představa. Je daný jako věc, ale přesto kulturní. S kulturou se nesetkáváme jako se soustavou myšlenek, je přece obsažena už ve světě, se kterým se seznamujeme. Ten sám je už vždycky světem interpretovaným, a tedy kulturním. Kulturu můžeme izolovat analyticky tak, že ji oddělíme od volních obsahů, ale to neznamená, že sama má pouze pomyslnou existenci. Právě naopak. Tím, že oddělíme volní obsahy, oddělujeme pouze to nahodilé (Durkheim 1926: 126-127), co být může a nemusí, a získáváme př́stup ke skutečnosti ustálené (nikoli ovšem fixní) v pozadí. Kulturu je tedy možno chápat přímo ontologicky jako skutečnost, v jejímž rámci probíhá sociální život.

\section{Sociologismus a mezilidská vzájemnost}

Programu kulturní sociologie nevyhovuje ani obraz Durkheima jako představitele radikálního holismu, který není schopen vnímat jedince a mikro-úroveň mezilidských interakcí. Durkheimovo teoretizování ve Společenské dělbě práce začíná právě na úrovni interakce. Věnuje se dvěma základním prríčinám, které k sobě pojí přátele - podobnosti a doplňující se různosti. Odtud vycházejí dva typy solidarity, které jsou osou celé knihy: mechanická

17 Srv.: „Látka tohoto základního výměru musí být tedy hledána mezi prvními znaky. Na druhé straně je jasno, že tento výměr musí obsahovat bez výjimky a bez rozdílu všechny jevy, které vykazují stejně tytéž znaky; nebot' nemáme důvodu ani možnosti mezi nimi si vybírati““(Durkheim 1926: 67). 
solidarita založená na podobnosti a organická solidarita založená na různosti, dělbě práce.

Společenská dělba práce je kniha nejobecnějších sociologických otázek, ale jejím tématem jsou zároveň dílčí otázky dělby práce, solidarity, práva. Máme to chápat tak, že do rámce své velké teorie Durkheim umist’uje dílčí témata ekonomická, právní a morální, nebo že rozumí společnosti právě jen jako výslednici těchto sfér? To je otázka, kterou si kulturní sociologie v př́stupu k Durkheimovu teoretizování ve Společenské dělbě práce musí klást. Pokud by platila druhá možnost, nemá jí tu Durkheim př́liš co nabídnout. Ale pokud jsme schopni udržet i první čtení, mohl by ji obohatit. Pokusím se proto předložit interpretaci hlavních pojmů, které Durkheim ve Společenské dělbě používá, a vztahů mezi nimi. Jde o pojmy solidarity a dělby práce. V jejich výkladu však bude dán důraz na výše jmenované dva typy lidské vzájemnosti, protože ty si celkem bez problémů zachovávají obecnost a nepřipouštějí některé nejednoznačnosti, které tyto pojmy provázejí.

\section{Solidarita}

Podobnost i doplňující se různost jsou zdůvodněním lidské prríchylnosti a sdružování, ale tyto základní mezilidské vztahy nemůžeme vnímat tak samozřejmě jako solidaritu. Pokud je solidarita citem, a u Durkheima pro to nacházíme podporu (Durkheim 2004: 55 nebo 193), nepochybně nebude jediným citem provázejícím kolektivní a mezilidské vztahy. To nás vede k otázce po dalších relevantních citech a také k nutnosti specifikace solidarity vzhledem k obecnější dvojici podobnost/různost.

U Durkheima je však solidarita často užívána nikoli ve významu dílčího citu, nýbrž spíš jako obecná vlastnost sociálního celku - jako jeho pevnost, stabilita a soudržnost (od lat. soli$d u s$ - pevný, celkový, celý), kterou jsme schopni zvnějšku pozorovat, bez ohledu na vnitřní stavy subjektu. Tomuto významu odpovídá i fakt, že solidaritu Durkheim se samozřejmostí klade do tradiční i moderní společnosti, pouze specifikuje její typy. Nezdá se mi smysluplné prít se o tom, který význam více odpovídá autorovu záměru. Spíše chci prozkoumat možnost chápat solidaritu afektivně, a tedy jako cosi bližšího paradigmatu kulturní sociologie. ${ }^{18}$

Mezi solidaritou-citem a dvěma typy mezilidské vzájemnosti (podobností a růzností) je myslím vcelku jednoznačný vztah. Solidarita je citem vyplývajícím z pocitu sounáležitosti. Dokážeme se vcítit do situace druhého, protože si sebe dokážeme představit na jeho místě. Cítíme, že jeho situace je potenciálně i naše vlastní. A právě tato společná potencialita je základem solidarity. S tím není v rozporu, že může být pocit’ována i mezi velice různými jedinci. I u nich se zakládá na tom, co je jim společné.

Vztah doplňující se různosti provázejí jiné city. To, co je odlišné, nemohu chápat prostřednictvím podobnosti se sebou samým, ale přijímám to proto, že mě doplňuje. Př́íkladem mohou být třeba hierarchické mocenské vztahy nebo úcta ke starším. Mladému člověku není přistupná zkušenost stáří, ale právě proto ji respektuje. Lze to potvrdit i na nejzákladnějším př́kladu, který Durkheim pro tento vztah uvádí, a sice na doplňujícím se vztahu mezi oběma

18 To, že je kulturní sociologie svázána s důrazem na afektivitu, je možno vyčíst z citace v poznámce 1. Důraz na afektivitu je obzvlášt’ patrný v díle Randalla Collinse (viz např́klad Collins 2008: 133). 
pohlavími. Nazvat ho solidaritou je nezvyklé a nevýstižné. Návodný je tu naopak typický výraz: přitažlivost. Ukazuje se v něm právě to, že zde není podstatná kolektivní identita, ke které oba jedinci př́sluší, ale hmatatelné sbližení, které prokáže, že jedna část se hodí $\mathrm{k}$ druhé. To u solidarity vůbec není podstatné.

Jistě není náhoda, že slovo solidarita se obvykle používá ve výrazech jako občanská solidarita, mezilidská solidarita, solidarita pracujících. ${ }^{19}$ Zde se právě zdůrazňuje jistý jednotný základ (občanství, lidskost, povolání), který nás váže a na němž se vztah solidarity zakládá. Nejsilnější vlny solidarity lze pozorovat při přírodních katastrofách, válečných konfliktech nebo hladomorech. Takové katastrofy se mohou odehrát kdekoli na světě a stále se můžeme cítit zasaženi a s postiženými solidarizovat. Není to ale doklad toho, že solidarita je univerzální mezilidský cit, ale spíš toho, jak silná je představa člověka jako univerzální kategorie a lidských práv vztahujících se na všechny lidské bytosti. Takto silná a široká je pouze v západní kultuře moderní doby. Ostatně si můžeme všimnout i jistých nuancí, které tuto domněnku potvrzují. Někteří lidé pocit’ují solidaritu ještě univerzálněji a vztahují ji nejen na rozumné, ale i na cítící bytosti. Zvířatům pomáhají z nouze i v př́padě, že se $\mathrm{k}$ nim v žádném funkčním vztahu nenacházejí. Jiným lidem je naopak tento postoj vnitřně nesrozumitelný a starají se o zvířata právě jen v určitém, jejich život doplňujícím, vztahu. Starají se o svého psa, protože je jejich nejlepší přítel, ale jiná zvířata pojídají, aniž by to pocit'ovali jako morální nesrovnalost.

Solidarita je silná tam, kde silně vnímáme i spolupř́islušnost. Někteří lidé cítí silně právě univerzální lidskost a pomáhají lidem nezávisle na tom, ze které země pocházejí, nebo si dokonce vybírají vzdálené země třetího světa, protože jsou nejchudší. To ale není nic obecného. Většinou je solidarita tím silnější, čím vydatnější je druhová blízkost. Nejspíš bude silnější mezi Čechy nebo v rámci jednoho oboru a nejvíce v rámci jedné rodiny. Češi jistě svými př́spěvky pomáhali i při velké asijské tsunami či haitském zemětřesení, ale pouze někteří. Jejich pomoc a účast byla obecně daleko silnější a častější v případě domácích povodní, i když jejich dopad nebyl zdaleka tak ničivý.

\section{Dělba práce}

Je nutné problematizovat i Durkheimovo spojení dělby práce, organické solidarity a vztahu doplňující se různosti. Dělba práce sice naznačuje jistou funkční diferencovanost, ale ta je až sekundární. V jejím základu je koordinační problém. Je zde práce, kterou je nutno vykonat, a jde o to, kdo se jí chopí. Ale aby takový problém mohl vůbec vzniknout, musí být všichni chápáni jako potenciální pracovníci. V základu dělby práce je tedy jistá společná základní úroveň, předpoklad mezilidské podobnosti, nikoli různosti. ${ }^{20}$

19 A nikoli třeba: solidarita manželů, solidarita matky a dítěte, solidarita velitele a podřízeného.

20 Označovat vztah muže a ženy jako dělbu práce je proto zavádějící, protože jejich vztah je založen na původní odlišnosti a dělba čehokoliv je až jeho sekundárním obsahem. Můžeme mluvit o tom, že pár si dělí různé domácí práce, že se dělí v péči o potomky, ale to opět jenom proto, že se jedná o práci, kterou mohou vykonat oba. Jejich vztah ale nevzniká na základě nějaké unifikované pracovní schopnosti, ale je založen na ryzí odlišnosti, která je vzájemně poutá. Durkheim se také 
Moderní společnost organické solidarity založená na rozvinuté dělbě práce je podmíněna kulturně specifickou představou jednotného lidství, které nerozlišuje předem dané společenské role. To potvrzuje i Weberův pohled na původ kapitalismu, jenž je spojen s univerzalizací práce jako údělu všech věřících. Durkheim chce sice pojem dělby práce chápat šířeji, ale uniká mu fakt, že v kulturní, politické a ekonomické vrstvě společnosti probíhal vývoj často protichůdným směrem. Zatímco ekonomicky šlo o postup od samozásobitelství k dělbě práce, ve sférée politické a kulturní proběhl vývoj opačný. Stř̌edověká Evropa tří oddělených stavů je ve srovnání s moderním občanským státem společností diferencovanou. Moderní společnost povstala až teprve tehdy, když byly hranice mezi stavy prolomeny a práce se stala čímsi, co je teprve třeba rozdělit. Na tomto základě se teprve mohl rozvinout problém dělby práce a úsilí o stále efektivnější specializaci. Zatímco Durkheim popisoval vývoj k moderní společnosti jako pohyb $\mathrm{k}$ různosti, Tocqueville jej viděl jako pohyb směrem $\mathrm{k}$ rovnosti. Nemusíme to chápat jako dva konfliktní postoje, uvědomíme-li si, že každý se vztahoval k jiné úrovni společnosti - Durkheim k ekonomické, zatímco Tocqueville k politické a kulturní (viz Tabulka 1).

Tabulka 1: RŮznost (doplňování) a podobnost (sounáležitost) ve vývoji od tradiční k moderní společnosti.

\begin{tabular}{|l|l|l|}
\hline \multicolumn{1}{|c|}{ Vývojová fáze společnosti } & Tradiční & Moderní \\
\hline Analytická úroveň & Stavovská společnost, různost identit & $\begin{array}{l}\text { Občanská společnost - jednotná } \\
\text { identita }\end{array}$ \\
\hline Kulturní & Předepsaná hierarchie & Všeobecné právo volit i být volen \\
\hline Politická & Samozásobitelství & Dělba práce \\
\hline Ekonomická &
\end{tabular}

Tmavě šedá pole značí vztahy založené na rưznosti, světle šedá na podobnosti.

Durkheim, bohužel, chtěl představu vývoje ke specializaci prosadit i v mimoekonomické sféře, čímž se vytvořila představa, že i hlubší kulturní pozadí je organizováno stejně jako dělba práce v ekonomice. Durkheima však nelze považovat za ekonomického deterministu. S ohledem na celé jeho dílo je to spíš nedokonalost jeho teorie, nikoli záměr. V Pravidlech jsme viděli, že společenský jev koncipoval jako to, co přesahuje volní složku. Rozhodně tedy nebylo jeho záměrem interpretovat společnost jako výslednici ekonomického rozhodování.

jednoznačně mýlil, když civilizační vývoj genderových vztahů odhadl jako pohyb směrem k větší specializaci pohlaví. 
Identita

Má-li kulturní sociologie těžit z Durkheimových myšlenek ve Společenské dělbě práce, bude v nich muset nalézt čistě kulturní rozměr. Kulturu chápe Alexander jako oblast kódů, narativů a sféru symbolickou. Domnívám se, že tento výčet můžeme rozšírit o pojem identity založený na dvou typech mezilidské vzájemnosti (spolupř́slušnosti/doplňující se různosti). Tak jako Alexander charakterizuje občanskou sféru pomocí kulturních kódů (demokratického a antidemokratického), můžeme ji chápat i jako dílčí následek změny v (sebe)chápání člověka, který se prosadil během osvícenství. Lidská identita přsstala být odvozována od původu a jedinec začal být chápán především jako př́slušník lidského druhu. Vývoj od tradiční k moderní společnosti je tedy vývojem od doplňující se různosti identit ke společné všelidské identitě. Identita samozřjejmě není v sociologické teorii žádným novým pojmem, ale její zasazení do kulturní sféry jí dává specifický význam. Je chápaná nikoli konstruktivisticky, ale právě positivisticky. Identita je tu brána jako daná skutečnost, jako předpoklad a výchozí bod lidského rozhodování a ne jako jeho výkon. Lidské jednání je jednáním osob, nelze jednat, aniž bychom sebe nechápali jako někoho. Základní vlastnost takto chápané identity je její původní socialita. Durkheim identitu rozlišil do dvou typů: 1) V rámci identity prvního typu se lidé chápou jako členové stejného celku. Součástí identity jedince je to, že to není jen jeho vlastní identita, ale zahrnuje i druhého. Jelikož patří oběma, ale zároveň ani jednomu osobně, má tendenci se osamostatnit do podoby kolektivní reprezentace. 2) Identita druhého typu je formována podle druhého jako jeho doplněk. Jsem tím, kým jsem, protože doplňuji druhého, s nímž, a případně s dalšími, tvoříme celek.

Kolektivní reprezentace je pojem, který se u Alexandera objevuje. Alexander (2010) ho používá třeba ve své práci o kampani před prezidentskými volbami v USA. Úkolem kandidáta $\mathrm{v}$ jeho interpretaci je se $\mathrm{v}$ průběhu kampaně prosadit jako kolektivní reprezentace celku. Musí dosáhnout toho, že bude vnímán jako symbol, který zastřešuje celek, podobným způsobem jako jiné symboly (státní vlajka, hymna, ústava, americké hodnoty). Kolektivní reprezentace ovšem není identitou, ale spíš je jejím průvodním jevem a prostředkem. Posiluje identitu tím, že jí dává symbolický tvar. Americké prezidentské volby jsou tak chápany jako periodický rituál obnovení kolektivní identity. Kolektivní reprezentace se ale vztahuje pouze k identitě založené na spolupř́slušnosti. Druhý základní typ identity u Alexandera chybí a chybí i širší představa o identitě člověka v moderní společnosti.

\section{Závěr}

Tento text se snažil ukázat, jak by mohl být rozšířen teoretický základ, který kulturní sociologie Jeffreyho Alexandera čerpá z díla Émila Durkheima. Pokusil jsem se překročit výlučnou orientaci na pozdní fázi klasikova díla a zaměřit se na první dvě velké knihy, které formovaly ranou fázi Durkheimovy sociologické dráhy.

V první části jsem chtěl upozornit na to, že positivismus vůbec nemusí být chápan jako myšlenkový směr, který se s kulturní sociologií vylučuje. Rozlišil jsem dva různé akcenty tohoto filosofického směru: metodologický (scientistický), jenž prosazuje jednotu vědecké metody, a ontologický, jenž obhajuje svébytnost společnosti a staví ji na roveň s předměty přírodních věd. Ač u Durkheima můžeme nalézt proklamace podporující oba tyto dílčí 
faktory, jím použitá metoda je praxi přírodních věd velmi vzdálená. Dílo Společenská dělba práce je interpretací soudobé společnosti, ve kterém nenajdeme žádná tvrdá data, natož pak matematické modely, měření, experimenty nebo jiné podobné postupy, které přírodovědeckou metodu charakterizují. ${ }^{21}$ Centrální metodologický spis Pravidla sociologické metody je, jak jsem se snažil tvrdit, spíše filosofickým pojednáním než soupisem vědeckých metod. Jeho jádrem je obhajoba svébytnosti společenské sféry. Důraz positivismu na to, co je zvnějšku dané, se u Durkheima realizuje jako obhajoba ryzí exteriority společnosti vůči jedincově vůli. Durkheim vymaňuje společnost z vlivu individuální vůle a chápe ji jako původnější determinantu, která tuto vůli preformuje. S ohledem na záměr kulturní sociologie se to dá chápat jako cesta za ekonomickou, politickou a sociální sféru, k základnější sféře kulturní. Positivismus lze tedy chápat jako směr souběžný se snahou kulturní sociologie.

Kulturní sféru jsem se snažil izolovat v díle Společenská dělba práce a doplnit odtud soubor narativ-symbol-kód pojmem identity. Problémem Durkheimovy teorie je nejasnost mezi ekonomickou a obecně sociologickou rovinou argumentace. Jeho záměr je nepochybně širší, ale ve své typologii solidarit a v představě vývoje směřujícího ke specializaci zachytil pouze ekonomickou rovinu věci. S odkazem na Tocquevilla jsem se snažil ukázat, že kulturní vývoj probíhal opačným směrem. Osvícenství přineslo ideu lidské rovnosti a bratrství a lidská identita se unifikovala, nikoli specializovala. Abychom identitu mohli řadit do kulturní sféry, musíme jí rozumět jako kulturně specifickému (sebe)chápání jednajících subjektů, které není výsledkem rozhodování, ale jeho předpokladem. V durkheimovském pojetí je to základní mezilidská konstelace, jež může nabývat dvou typů - sounáležitosti a doplňování. Je založena na dvou typech mezilidské vzájemnosti, které Durkheimovi slouží jako výchozí bod pro jeho typologii solidarit.

Identita je v posledních letech velmi silným tématem sociologických studií, ale ve velké většině je chápána konstruktivisticky. Je-li v názvu textu identita, pak zpravidla v sousloví sociální konstrukce identity. Většinou se tyto studie snaží ukázat sociální determinovanost toho, co je bráno jako samozřejmě platné. Konstruktivistické teorie jsou platné především pro výzkum společenských nerovností různých typů, tedy tam, kde je určitá identita vnímána jako zraňující. (Post)moderní společnost ale stíhá i opačný typ problémů - krize identity či identitární panika (Bělohradský). Přisouzené identity je někdy obtížné se zbavit, ale stejně tak je těžké ji nalézt tam, kde je oslabená či narušená. V tomto ohledu by durkheimovské pojetí identity mohlo být př́nosné, protože vyznívá přesně opačným směrem než konstruktivistické teorie. Nesnaží se identity zpochybňovat, ale naopak hledá jejich základ. Identita je tu chápána jako nutnost, základ jednání, který lze objevit za povrchovějšími a zjevnějšími vrstvami sociálního života.

21 Jiná v tomto ohledu je jistě Sebevražda, nasycená spoustou statistik, ze kterých se odvozují prŕíciny sebevražednosti. Je ovšem otázkou, zda je nepovažovat pouze za vhodný argumentační nástroj, který podložil autorovy teze. Již bylo upozorněno na to, že Durkheimova data umožňují i zcela jiné interpretace (van Poppel a Day 1996). Jeho typologie sebevraždy, jež leží v jádru práce, není získaná žádnou statistickou metodou typu analýzy latentních struktur. Je to autorův postulát, jenž plynule navazuje na jeho teoretické úvahy v předchozích dílech. Např́ílad o anomii mluví Durkheim už ve Společenské dělbě práce, není to žádný výsledek, který se jednoduše ukázal v datech. 


\section{Literatura}

ALEXANDER, Jeffrey. Theoretical Logic in Sociology. The Antinomies in Classical Thought: Marx and Durkheim. 1. vyd. Berkeley: University of California Press, 1982. ISBN 0710090498.

ALEXANDER, Jeffrey (ed.). Durkheimian Sociology: Cultural Studies. Cambridge: Cambridge University Press, 1988. ISBN 0521396476.

ALEXANDER, Jeffrey. Action and Its Environments. In ALEXANDER, Jeffrey (ed.), Action and Its Environments, Toward a New Synthesis. New York: Columbia University Press, 1988. ISBN 0231062087.

ALEXANDER, Jeffrey. The Meanings of Social Life: A Cultural Sociology. Oxford: Oxford University Press, 2003. ISBN 0195306406.

ALEXANDER, Jeffrey. The Civil Sphere. New York: Oxford University Press, 2006. ISBN 0195162501.

ALEXANDER, Jeffrey. The inner development of Durkheim's sociological theory: from early writings to maturity. In ALEXANDER, J., SMITH, P. (eds.). The Cambridge Companion to Durkheim. Cambridge: Cambridge University Press, 2008, s. 136-160. ISBN 052100151X.

ALEXANDER, Jeffrey. Performance of Politics. 1. vyd. Oxford: Oxford University Press, 2010. ISBN 0199744467.

ARON, Raymond. Main currents in sociological thought. II, Durkheim, Pareto, Weber. Harmondsworth: Penguin Books, 1967. ISBN 0297763105.

COLLINS, Randall. The Durkheimian movement in France and in World Sociology. In ALEXANDER, J. (ed.) Durkheimian Sociology: Cultural Studies. Cambridge: Cambridge University Press, 1988, s. 101-103. ISBN 0521396476.

DURKHEIM, Émile. Pravidla sociologické metody. Praha: Masarykova Sociologická společnost, 1926.

DURKHEIM, Émile. Společenská dělba práce. Brno: CDK, 2004. ISBN 80-7325-041-1.

GIDDENS, Anthony. Capitalims and Modern Social Theory. Cambridge: Cambridge University Press, 1971. ISBN 0521097851.

GEERTZ, Clifford. Zhuštěný popis. K interpretativní teorii kultury. In GEERTZ, C. Interpretace kultur. Praha: Sociologické nakladatelství, 2000, s. 13-45. ISBN 80-85850-89-3.

LUKES, Steven. Émile Durkheim: his life and work: a historical and critical study. London: Allen Lane, 1973. ISBN 0060127279.

NISBET, Robert. The Sociology of Émile Durkheim. London: Heinemann, 1975. ISBN 019501734X.

PARSONS, Talcott. The Structure of Social Action, Volume I. New York: The Free Press, 1968. ISBN 0029242401.

POPPEL, Frans van, DAY, Lincoln. A Test of Durkheim's Theory of Suicide-Without Committing the ,Ecological Fallacy'. American Sociological Review, 1996, roč. 61, č. 3. ISSN 0003-1224.

THOMPSON, Ken. Emile Durkheim. London: Routledge, 1982. ISBN 0415285313.

SKOVAJSA, Marek. Relativní autonomie kultury v Alexanderově kulturní sociologii. Sociologický časopis, 2012, vol. 48, No. 2, s. 225-246. ISSN 0038-0288.

WALLACE, Ruth A., HARTLEY, Shirley F. Religious elements in friendship: Durkheimian theory in empirical context. In ALEXANDER, J. (ed.). Durkheimian Sociology: Cultural Studies. Cambridge: Cambridge University Press, 1988, s. 93-107. ISBN 0521396476.

\section{Autor}

Vit Horák je doktorským studentem sociologie na Institutu sociologických studií Fakulty sociálních věd Univerzity Karlovy. Tamtéž je i tajemníkem doktorského studia, vede semináŕ k dějinám sociologie a vyučuje kurz věnovaný Émilu Durkheimovi. Odborně se zajímá především o teorii jednání v tradici Maxe Webera, Talcotta Parsonse a Jürgena Habermase a filosofickou hermeneutiku Hanse-Georga Gadamera.

Kontakt: motykamachek@gmail.com 